Anna Dobrovolska,

PhD (Candidate of Physical and Mathematical Sciences), associate professor, Department of Medical Informatics, Medical and Biological Physics, Ivano-Frankivsk National Medical University, 2, Halytska Str., Ivano-Frankivsk, Ukraine

\title{
MODEL OF METHODICAL SYSTEM OF THE FORMATION OF THE IT COMPETENCE OF FUTURE DOCTORS AND PHARMACISTS IN THE PROCESS OF TEACHING SCIENTIFIC DISCIPLINES
}

The concept of information technology competence (IT competence) of future doctors and pharmacists has been formulated in the article. The criteria and indices of its maturity have been characterized within the limits of the following components: motivational and evaluative, cognitive, technological, operational, communication-oriented, personevaluative, reflexive, axiological, emotional and volitional. The model of the methodical system of the formation of the IT competence in students in the process of teaching scientific disciplines to them, which consists of 5 units, has been developed. It has been also considered that the preconditions for the formation of the IT competence in future specialists within the limits of this methodical system are the modern requirements on informatization of higher medical and pharmaceutical education under the conditions of society informatization, social demand for the preparation of doctors and pharmacists who have the IT competence, and also contradiction between the declared use of the IT competence in the process of teaching and its application in the professional activity. The strategically-normative unit of the developed model of the methodical system takes into account the industry standards of higher education, curricula of preparation of doctors and pharmacists, typical teaching programmes of scientific disciplines. The target unit of this model involves the formation of the IT competence of future doctors and pharmacists according to the results of teaching scientific disciplines. The theoretical and methodological unit of the model considers pedagogical conditions, approaches and principles of the formation of the IT competence of future specialists. The technological unit is focused on the constituents, components and stages of the formation of the above mentioned competence. The evaluative unit describes the criteria of effectiveness and the levels of the formedness of the IT competence, and also involves the criteria of its evaluation and the means of control.

Keywords: IT competence, criterion, index, methodical system, model, components, structure, principles, features, regularities.

Подано до редакиії 15.06.2016

Реиензент: д. пед. н., проф. Неллі Василівна Лисенко

УдК: $372.1+372.044+372.24$

Лариса Олександрівна Мостова, вчитель початкових класів, Одеський НВК «Гімназія №2», вул. Гаванна, 5А, м. Одеса, Украӥна

\section{СТИМУЛЮВАННЯ ПІЗНАВАЛЬНОЇ АКТИВНОСТІ МОЛОДШИХ ШКОЛЯРІВ ЗАСОБАМИ ДИДАКТИЧНИХ ІГОР}

\begin{abstract}
Передумовою успішності в навчанні молодших школярів виступає пізнавальна активність, щзо розглядається як риса особистості, яка виявляється в ї̈ ставленні до пізнавальної діяльності, прагнення до самостійної діяльності, спрямованої на засвоєння індивідом соиіального досвіду, накопичених людством знань $i$ способів діяльності, а також знаходить вияв у якості пізнавальної діяльності. Важливу роль у процесі регуляџії пізнавальної активності молодших школярів відіграє емоційний чинник, який значною мірою може забезпечити використання у прочесі навчання дидактичних ігор. Сутність дидактичних ігор полягає у виріменні пізнавальних завдань, поставлених у иікавій формі. Автором запропоновано приклади застосування дидактичних ігор на уроках читання, математики, украӥнської мови в початковій школі.
\end{abstract}

Ключові слова: молодші школярі, пізнавальна активність, дидактичні ігри.

Постановка проблеми. В сучасних умовах модернізації роботи початкової школи виникає необхідність глибокого осмислення способів і методів навчання молодших школярів, що традиційно існують, визначення перспектив і умов застосування в освітньому процесі розвивальних технологій, спрямованих на розвиток пізнавальних здібностей учнів. Проблема,
3 якою стикається вчитель початкової ланки освіти, полягає в тому, що до школи приходять діти з різним розвитком, підготовленістю до навчання у школі, темпом роботи, швидкістю запам'ятовування, спостережливістю, зосередженістю тощо. Отже, важливим завданням учителя є врахування індивідуальних особливостей учнів, створення таких умов, які б сприяли 
ефективному навчанню відповідно до рівня розвитку учнів, забезпечували б у процесі навчання подальший розвиток здібностей та інтересів дітей [3].

Успішність молодших школярів, на думку науковців (Н. Бібік, В. Давидов, Д. Ельконін, О. Савченко та ін.), забезпечується шляхом цілеспрямованого формування й розвитку їхньої пізнавальної активності й самостійності. Дидактичні ігри допомагають учням долати пізнавальні труднощі, усувають страх, почуття дискомфорту, що позначається на успішності дітей та їхній пізнавальній активності [5].

Аналіз останніх досліджень і публікацій 3 проблеми. Зазначимо, що для учнів початкової школи, поряд із провідною навчальною діяльністю, залишається актуальною ігрова діяльність. Проблема ігрової діяльності завжди перебувала в центрі уваги вчених, зокрема іiі досліджували П. Блонський, Д. Ельконін, Ж. Піаже, С. Рубінштейн, К. Ушинський, 3. Фрейд, які наголошували на визначній ролі гри в онтогенезі особистості, у розвитку основних психічних функцій, самоврядуванні і саморегулюванні особистості, засвоєнні й використанні людиною суспільного досвіду.

Загальнотеоретичні аспекти проблеми дидактичної гри були предметом досліджень Є. Анікєєвої, А. Деркача, А. Капської, Н. Кудикіної, П. Підкасистого, О. Савченко, Л. Терлецької та ін. Ефективність використання дидактичних ігор у навчанні молодших школярів доведено в працях Ш. Амонашвілі, Н. Бібік, М. Вашуленка, Б. Друзя, С. Короткова, М. Лацаруса, М. Монтессорі, М. Сикитинської, Ф. Фребеля, С. Холла, Г. Цукерман, Т. Шмакової та ін. Незважаючи на те, що вченими і вчителями-практиками наголошується на важливій ролі дидактичних ігор у стимулюванні пізнавальної активності молодших школярів, застосування дидактичних ігор на уроках, на жаль, ще не стало реалією сучасної початкової школи.

Мета статті - розглянути сутність феномена «пізнавальна активність», визначити роль дидактичних ігор у стимулюванні пізнавальної активності молодших школярів.

Методами дослідження виступили аналіз наукової і методичної літератури, спостереження, бесіди, вивчення результатів навчальної діяльності учнів початкової школи.

Виклад основного матеріалу дослідження. Зауважимо, що передумовою успішності в навчанні молодших школярів виступає пізнавальна активність, яка, за Л. Аристовою, виявляється у процесі їі перетворювальної діяльності й передбачає ставлення суб'єкта до довколишніх явищ і предметів [1, с. 34]. При цьому автор наголошує на тому, що активність виступає невід'ємною умовою пізнавальної діяльності суб'єкта і змінюється відповідно до того, як змінюється рівень і характер змісту його діяльності. Д. Вількєєв визначає пізнавальну активність як психічний стан, який виявляється в налаштуванні на розв'язання інтелектуальних завдань [2].
Як діяльний стан учня, який характеризується прагненням до навчання, розумовою напругою і виявом вольових зусиль у процесі оволодіння знаннями розглядає пізнавальну активність І. Харламов [8, с. 31]. За визначенням Т. Шамової [9], активність у навчанні - це не просто діяльний стан учня, а якість цієї діяльності, в якій виявляється особистість самого учня з його ставленням до змісту, характеру діяльності і прагненням мобілізувати свої морально-вольові зусилля для досягнення навчально-пізнавальних цілей.

Ми дотримуємося визначення В. Лозової [4], яка розглядає поняття пізнавальної активності як рису особистості, що виявляється в її ставленні до пізнавальної діяльності, яка передбачає стан готовності, прагнення до самостійної діяльності, спрямованої на засвоєння індивідом соціального досвіду, накопичених людством знань і способів діяльності, а також знаходить вияв у якості пізнавальної діяльності.

Розвитку пізнавальної діяльності молодших школярів сприяє запровадження в освітній процес ігрової діяльності, оскільки гра є найприроднішою і найпривабливішою діяльністю для молодших школярів. Ще К. Ушинський зазначав, що завдання початкового навчання полягає в тому, щоб зробити серйозне заняття для дитини цікавим, оскільки кожна здорова дитина потребує діяльності і до того ж серйозної діяльності.

Науковці визначають сутність гри як форму спілкування (М. Гончаров, Т. Ладивір, М. Лісіна, В. Семенов, В. Сушко, Н. Філатова), форму діяльності (Л. Виготський, Д. Ельконін), умову розумового розвитку (П. Каптєрєв, С. Покровський, С. Рубінштейн, I. Сікорський, А. Смирнов).

Гра в початковій ланці є засобом пізнання довколишнього світу і себе в ньому, усвідомлення дітьми мети своєї діяльності, опредмечування абстрактних понять, розвитку творчої уяви та здібностей, встановлених людяних взаємин. Більшість вчителів використовує гру як засіб цілеутворення педагогічної діяльності та інтерпретації іiі в особистості дії учня. Гра допомагає розвивати творчу уяву та творчі здібності дитини [6, с. 5].

С. Шмаковим [10, с. 14] гра розглядається як феномен педагогічної культури, яка виконує такі важливі функції, як-от:

- функцію соціалізації: гра є потужним засобом включення дитини в систему суспільних відносин, засвоєння нею багатств культури;

- функцію міжнаціональної комунікації: гра дозволяс дитині засвоювати загальнолюдські цінності, культуру представників різних національностей, оскільки ігри національні і водночас інтернаціональні, міжнаціональні, загальнолюдські;

- функцію самореалізації дитини в грі як «полігоні людської практики»: гра дозволяє, з одного боку, побудувати i перевірити проект зняття конкретних життєвих труднощів у практиці дитини, 3 іншого виявити недоліки досвіду;

- комунікативну функцію: гра дозволяє дитині 
ввійти в реальний контекст складних людських комунікацій;

- діагностичну функцію: надає можливість педагогові діагностувати різні прояви дитини (інтелектуальні, творчі, емоційні та ін.). Водночас гра - «поле самовираження», в якому дитина перевіряє свої сили, можливості у вільних діях;

- терапевтична функція гри полягає у використанні гри як засобу подолання різних труднощів, що виникають у дитини в поведінці, спілкуванні, навчанні.

- функцію корекції: внесення позитивних змін, доповнень до структури особистісних показників дитини. У грі цей процес відбувається природно, м'яко.

Крім цього, гра відіграє й важливу виховну роль, оскільки сприяє формуванню дружного колективу, самостійності, позитивного ставлення до праці, виправленню деяких відхилень у поведінці окремих дітей тощо.

О. Ноздровою в процесі наукового пошуку встановлено, що особливості розвитку молодших школярів пов'язані з тим, що в цьому віці в школярів не сформовано стійкі мотиви навчання, у них переважають ігрові інтереси, мимовільна увага над довільною, наочно-образне мислення, недостатній розвиток вольових якостей. Тому важливу роль у процесі регуляції пізнавальної активності молодших школярів відіграє емоційний чинник, який значною мірою може забезпечити використання у процесі навчання дидактичних ігор. Процес формування пізнавальної активності за допомогою дидактичної гри, акцентує автор, зумовлений зростанням активності самої дитини, посиленим проявом ii інтересу до пізнання, тобто ефективність навчання перебуває в прямій залежності від активності самої дитини [5].

Дидактична гра - це метод навчання, що передбачає, з одного боку, наявність ігрової дії, за допомогою якої формуються певні якості особистості (увага, спостережливість, пам'ять), розвивається мислення, виявляються творчі здібності школяра, самостійність, ініціатива, а 3 іншого - розв'язує певні дидактичні завдання: вивчення нового матеріалу, повторення i закріплення вивченого матеріалу, формування трудових умінь і навичок, використання здобутих знань на практиці $[5$, с.8].

Сутність дидактичних ігор полягає у вирішенні пізнавальних завдань, поставлених у цікавій формі. Вирішення пізнавальної задачі пов'язане з розумовою напругою, з подоланням труднощів, що привчає дитину до розумової праці. Одночасно розвивається логічне мислення дітей. Засвоюючи або уточнюючи в дидактичній грі той або інший програмний матеріал, діти вчаться спостерігати, порівнювати, класифікувати предмети за певними ознаками; застосовувати чітку і точну термінологію, зв'язно розповідати; описувати предмет, називати його дії та якості; виявляють кмітливість, винахідливість тощо.

Завдання вчителя полягає в тому, щоб знайти ма- ксимум педагогічних ситуацій, у яких може бути реалізовано прагнення дитини до активної пізнавальної діяльності. Він повинен постійно вдосконалювати процес навчання, що дозволяє дітям ефективно й якісно засвоювати програмовий матеріал. Гра активізує психічні процеси діяльності учня молодшого шкільного віку (відчуття, сприймання, мислення, уяву, пам'ять, волю, мову), які призводять до позитивних зрушень у розвитку школяра. Успіх проведення гри залежить від дотримання вимог: ігри мають відповідати навчальній програмі; ігрові завдання мають бути не надто легкими, проте й не дуже складними; відповідність гри віковим особливостям учнів; різноманітність ігор; залучення до ігор учнів усього класу [7, с. 44-53]. Використання на уроках дидактичних ігор та ігрових моментів робить процес навчання цікавим, створює у дітей бадьорий, творчий настрій, полегшує засвоєння навчального матеріалу. Наведемо кілька прикладів таких дидактичних ігор.

На уроках читання можна провести різноманітні дидактичні ігри, спрямовані на закріплення вивченого матеріалу: «Скільки слів у реченні?», «Так» чи «ні», «Короткі і довгі слова», «Жива сцена», «Листоноша приніс листа», «Екскурсія», «Подаруй іграшку», «Цікаві слова», «Ходить буква рядами», «Вкажи слово», «Кому дзвонила жирафа», «Відгадай назви професій», «Назви одним словом», «Незвичайний поїзд», «Допоможи Червоному Капелюшку», «Казочки 3 помилками» та ін.

Зокрема, з метою закріплення знання про букви i звуки, засвоєння їх зображення доцільно проводити гру «Впізнай на осліп». Дітям пропонується впізнати вирізану з твердого паперу літеру на дотик. Надалі діти називають звуки, які позначають цю літеру, добирають слова, які з неї починаються.

Для закріплення знань щодо складової побудови слів можна провести дидактичну гру «Склади своє ім'я». На столі розкладаються картки із складовими імен учнів класу. Завданням є правильно скласти своє ім'я.

Гра «Живі слова» спрямована на розвиток мовлення, вдосконалення вмінь використовувати слова в реченні. Для цього до дошки викликаються учні, які виконуватимуть роль «живих слів», які записані на картках. Діти повинні скласти 3 цих слів речення, називаючи по черзі слова, а учні-«слова» стають в тому порядку, як вони звучать у реченні.

Значна кількість цікавих для дітей дидактичних ігор використовується й на уроках математики: «Математичний футбол», «Математичне доміно», «Шифрувальники», «Туристи», «Конструктор», «Виправ помилку» та ін.

Так, $з$ метою розвитку уваги, кмітливості; закріплення знань нумерації чисел, «сусідів числа» використовується гра «Знайди своє місце». У грі приймають участь команди по 10 учнів, кожний учень отримує нумераційну картку. Ведучий виконує завдання, інші виконують його вказівки. Вчитель зав'язує очі одному 3 гравців, обертає його, промовляючи: «Крутись, вер- 
тись - На своєму місці з'явись». У цей час гравці міняються місцями. Ведучий повинен швидко поставити дітей по порядку номерів та знайти своє місце в цьому ряду.

Для розвитку уваги, математичних умінь і навичок доцільно провести «Математичну естафету». Для цього вчитель заздалегідь записує на дошці три стовпчики прикладів; учні кожного ряду по черзі вибігають до дошки і записують відповіді. Перемагає та команда, яка швидше впорається із завданням та допустить менше помилок.

На уроках української мови проводяться дидактичні ігри: «Ланцюжок», «Злови п’ять слів», «Уважні долоньки», «М'ячик», «Збери слово», «Хмарка», «Збирання грибочків», «Який склад з’їв буквоїд», «Допоможи Вінні Пуху» «Навпаки».

Метою дидактичної гри «Збери букет» $е$ формування в дітей уміння розрізняти м'які приголосні та тверді. На дошці малюнки дівчинки Лесі та хлопчика Іванка, квітів. Вчитель говорить слова: Леся та Іванко збирають букет для мами. Але Леся може брати тільки квіти, назви яких починаються 3 м'яких приголосних. А Іванко - назви яких починаються 3 твердих

\section{ЛІТЕРАТУРА}

1. Аристова Л. П. Активность учения школьников / Л. П. Аристова. - М. : Просвещение, 1968. - 138 с.

2. Вилькеев Д. В. Познавательная деятельность учащихся при проблемном характере обучения основам наук в школе / Д. В. Вилькеев. - Казань, 1967. - 76 с.

3. Логачевська С. П. Методика диференційованого навчання. 150 фрагментів уроків мови і математики в 1-4 класах 3 елементами диференціації / Світлана Панасівна Логачевська. - Кам'янецьПодільський : Абетка, 2005. - 240 с.

4. Лозова В. І. Цілісний підхід до формування пізнавальної активності школярів / В. І. Лозова. - 2-е вид., доп. - Х. : ОВС, 2000. - 164 с.

5. Ноздрова О. П. Дидактична гра як засіб стимулювання пізнавальної активності учнів 6-7-річного віку : автореф. на здобуття наук. ступеня канд. пед.

\section{REFERENCES}

1. Aristova, L. P. (1968). Aktivnost ucheniya shkolnikov [Activity level of pupils' studies]. Moscow: Prosveshhenie [in Russian].

2. Vilkeev, D. V. (1967). Poznavatelnaya deyatelnost uchaschikhsya pri problemnom kharaktere obucheniya osnovam nauk $v$ shkole [Students' cognitive activity in the process of problem-based learning of elements of sciences at school]. Kazan [in Russian].

3. Lohachevska, S. P. (2005). Metodyka dyferentsiiovanoho navchannia. 150 fraghmentiv urokiv movy $i$ matematyky $v$ 1-4 klasakh $z$ elementamy dyferentsiatsii [Differential educational technology. 150 fragments of language and maths lessons in 1-4 forms with the elements of differentiation]. KamianetsPodilskyi: Abetka [in Ukrainian].

4. Lozova, V. I. (2000). Tsilisnyi pidkhid do formuvannia piznavalnoi aktyvnosti shkoliariv [Holistic приголосних. Допоможіть дітям. Лесі допомагають дівчатка, а Іванкові - хлопчики. Діти виходять до дошки і групують квіти відповідно до завдання.

Задля формування в дітей уміння розрізняти приголосні та голосні букви можна провести гру «Буква заблукала». На дошці розвішуються голосні та приголосні букви, які переплутав Незнайко. Голосні: «у»,

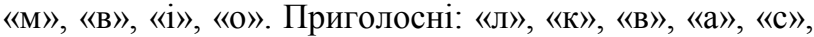
«и», «н». Діти знаходять ті букви, які переплутав Незнайко, і ставлять їх на місце.

Висновки та перспективи подальших досліджень. Відтак, застосування дидактичних ігор на уроках в початковій школі $є$ засобом стимулювання пізнавальної активності молодших школярів, в ході якої відбувається пізнання предметів та явищ довколишньої дійсності, а також розвиваються мислення, пам'ять, увага, уява. Перспективу подальших досліджень вбачаємо у розробці методичних рекомендацій щодо впровадження в навчально-виховний процес початкової школи ігрової творчої діяльності, спрямованої на стимулювання пізнавальної активності молодших школярів у позаурочний час.

наук : спец. 13.00.09 «Теорія навчання» / О. П. Ноздрова. - Харків, 2008. - 20 с.

6. Пидкасистый П. И. Технология игры в обучении и развитии / П. И. Пидкасистый, Ж. С. Хайдаров. - М. : РПА, 1996. - 269 с.

7. Плешакова А. Б. Игровые технологии в учебном процессе: [Пед. вузы] / А. Б. Плешакова // Современные проблемы философского знания. - Пенза, 2002. - Вып. 3. - С. 44-53.

8. Харламов И. Ф. Как активизировать учение школьников / И. Ф. Харламов. - Минск : Народная асвета, 1975. - 208 с.

9. Шамова Т. И. Активизация учения школьников / Т. И. Шамова. - М. : Педагогика, 1982. - 208 с.

10. Шмаков С. А. Игры учащихся - феномен культуры / С. А. Шмаков. - М. : Новая школа, 1994. $240 \mathrm{c}$.

approach to pupils' cognitive activity formation]. ( $2^{\text {nd }}$ ed., rev.). Kharkiv: OVS [in Ukrainian].

5. Nozdrova, O. P. (2008). Dydaktychna hra yak zasib stymuliuvannia piznavalnoi aktyvnosti uchniv 6-7richnoho viku [Didactic game as means for stimulation of the cognitive activity among 6-7-year-old pupils]. Extended abstract of candidate's thesis. Kharkiv [in Ukrainian].

6. Pidkasistyi, P. I., \& Khaidarov, Zh. S. (1996). Tekhnologiya igry $v$ obuchenii $i$ razvitii [Game technology in teaching and development]. Moscow: RPA [in Russian].

7. Pleshakova, A. B. (2002). Igrovye tekhnologii v uchebnom protsesse: [Ped. vuzy] [Game technologies in educational process: (Pedagogical universities)] // Sovremennye problemy filosofskogo znaniya Contemporary problems of Philosophy. (Vol.3). (pp. 4453). Penza [in Russian]. 
8. Kharlamov, I. F. (1975). Kak aktivizirovat ucheniye shkolnikov [How to activate pupils' learning]. Minsk: Narodnaya asveta [in Russian].

9. Shamova, T. I. (1982). Aktivizatsiya ucheniya shkolnikov [Intensification of pupils' learning]. Moscow: Pedagogika [in Russian].
10. Shmakov, S. A. (1994). Igry uchaschikhsya fenomen kultury [Games of pupils - culture phenomenon]. Moscow: Novaya shkola [in Russian].

Лариса Александровна Мостовая, учитель начальных классов, Одесский УВК «Гимназия №2», ул. Гаванная, 5А, г. Одесса, Украина

\section{СТИМУЛИРОВАНИЕ ПОЗНАВАТЕЛЬНОЙ АКТИВНОСТИ МЛАДШИХ ШКОЛЬНИКОВ СРЕДСТВАМИ ДИДАКТИЧЕСКИХ ИГР}

Важной задачей учителя начальной школы является учет индивидуальных особенностей учеников, создание условий, способствующих эффективному обучению в соответствии с уровнем их развития и обеспечивающих в процессе обучения дальнейшее развитие способностей и интересов детей. Предпосылкой успешности в обучении младших школьников выступает познавательная активность, рассматриваемая как черта личности, проявляющаяся в ее отношении к познавательной деятельности и предусматривающая состояние готовности, стремление к самостоятельной деятельности, направленной на усвоение индивидом социального опыта, накопленных человечеством знаний и способов деятельности, а также в качестве познавательной активности. Развитию познавательной активности учащихся способствует внедрение в образовательный процесс начальной школы игровой деятельности, поскольку игра является естественной и привлекательной деятельностью для детей младшего школьного возраста. Важную роль в процессе регуляции познавательной активности младших школьников играет эмоциональный фактор, который в значительной степени может обеспечить использование в процессе обучения дидактических игр. Процесс формирования познавательной активности при помощи дидактической игры обусловлен ростом активности самого ребенка, усиленным проявлением его интереса к познанию, то есть эффективность обучения находится в прямой зависимости от активности самого ребенка. Дидактические игры помогают учащимся преодолевать познавательные сложности, убирают страх, ощущение дискомфорта, что сказывается на успеваемости детей и их познавательной активности. Сущность дидактических игр заключается в предложении детям познавательных задач, поставленных в интересной форме, решение которых связано с умственным напряжением, преодолением трудностей, что способствует формированию логического мышления, приучению детей к умственной деятельности. Усваивая или уточняя в дидактической игре тот или иной учебный материал, дети учатся наблюдать, сравнивать, классифицировать предметы по определенным признакам, применять четкую и точную терминологию, связно рассказывать, описывать предмет, называть его действия и качества, проявляют сообразительность, изобретательность и т. д. Задача учителя состоит в том, чтобы найти максимум педагогических ситуаций, в которых может быть реализовано стремление ребенка к активной познавательной деятельности. Он должен постоянно усовершенствовать процесс обучения, что позволит детям эффективно и качественно усваивать программный материал. Автором предложены примеры использования дидактических игр на уроках чтения, математики, украинского языка в начальной школе.

Ключевые слова: младшие школьники, познавательная активность, дидактические игры.

\section{Larysa Mostova, primary school teacher, Odesa Learning and Education Complex “Gymnasium №2”, 5A, Havanna Str., Odesa, Ukraine}

\section{PROMOTING COGNITIVE ACTIVITY OF YOUNG SCHOOLCHILDREN BY MEANS OF DIDACTIC GAMES}

An important objective of elementary school teacher is taking into account the individual characteristics of pupils, creating conditions contributing to effective learning according to the pupils' level of development and providing further development of abilities and interests of children within the learning process. An important prerequisite for success in the training of younger schoolchildren is cognitive activity, regarded as a personality trait, manifested in its attitude to cognitive activity and providing a state of readiness, the desire for independent activity aimed at the mastering of individual social experience, accumulated knowledge and ways of life of humanity; it also manifests itself as cognitive activity. The progress of pupils' cognitive activity is contributed by the implementation of game activity in the elementary school educational process, as the game is a natural and attractive activity for young schoolchildren. The emotional factor plays an important role in the regulation of cognitive activity of young schoolchildren, and it can largely ensure the use of didactic games in the learning process. The process of cognitive activity formation by means of didactic games is caused by the growth of a child's activity; enhanced display of his/her interest in cognition, that is, efficiency of learning is directly dependent on the activity of the child. Didactic games help pupils overcome cognitive difficulties, 
fear, discomfort, which affects the progress of children and their cognitive activity. The essence of didactic games is to offer the children cognitive tasks in an interesting way, their solution is connected with the mental strain, overcoming difficulties, which contribute to the formation of logical thinking; consequently, children get accustomed to the mental activity. Learning and specifying any kind of educational material in the didactic game, children learn to observe, to compare, to classify objects according to certain criteria, to apply the clear and precise terms, to have coherent speech, to describe the object, name its actions and qualities, be quick-thinking, resourceful, and so on. A teacher's task is to find maximum pedagogical situations; by their means child's attitude to active cognitive activity can be realized. He/she must constantly improve the learning process that will enable children effectively and efficiently master the program material. The author offers examples of the use of didactic games at the reading lessons, mathematics, the Ukrainian language in elementary school.

Keywords: young schoolchildren, cognitive activity, didactic games.

Рецензент: д. пед. н., проф. І. В. Бужина

Подано до редакиії 15.06.2016

УДК: 001.8+37.015-004.247

\author{
Раиса Юрьевна Мартынова, \\ доктор педагогических наук, профессор, член-корреспондент НАПН Украины, \\ заведуюшая кафедрой западных и восточных языков и методики их обучения, \\ Южноукраинский национальный педагогический университет имени К. Д. Ушинского, \\ ул. Старопортофранковская, 34, м. Одеса, Украина
}

\title{
ХАРАКТЕРИСТИКА ПЕДАГОГИЧЕСКОЙ ИНТЕГРАЦИИ В ИССЛЕДОВАНИЯХ ОТЕЧЕСТВЕННЫХ И ЗАРУБЕЖНЫХ УЧЕНЫХ
}

В статье представлена дифференщиащия понятий «межпредметные связи» $и$ «интегрированное обучение» $u$ изложена краткая история развития педагогической интеграции на основе совершенствования межпредметньх связей до уровня их слияния в единую педагогическую общчноть. В настоящее время педагогическая интеграция прослеживается во всех ее формах: во взаимосвязи действий по обучению и воспитанию молодежи; во взаимосвязи содержания обучения различным дисциплинам, причем не только близким (математика, физика), но и разноплановым (информатика, иностранный язык); во взаимосвязи видов деятельности по отнотению к изучению основного предмета. Реализуется педагогическая интеграция путем создания «практического синтеза», то есть: соединения в один учебный предмет содержания смежных предметов; применения однотипных приемов и методов обучения синтезируемому предмету; слияния организационных форм обучения разным предметам в одно организационнометодическое единство, функционирующее в одном процессе обучения.

Ключевые слова: педагогическая интеграция, межпредметные связи, процессуальная общность, практический синтез, смежные науки, разнотипные предметы, интеграчия и дифференциичия.

Современный этап развития общества характеризуется стремительным притоком информации во многих ранее существующих областях знаний, а также развитием новых научных направлений, обусловленных появлением новых форм материального и духовного мира. Эта особенность современного развития окружающей действительности выражена Р. Арцишевским следующим образом: «В наше время на протяжении жизни одного поколения происходит больше перемен, чем в условиях традиционного общества за несколько столетий. Одной из наиболее значимых перемен является переход к информационному обществу. ... и поэтому в таких условиях возникают новые и, возможно, более сложные проблемы в современном образовании» [1, с. 45], требующие реконструкции его структуры и содержания как в средних, так и высших учебных заведениях.
Обеспечить школьников и студентов знаниями о новых открытиях во вновь возникаемых отраслях науки, техники и производства, и при этом не ущемить их в изучении основополагающих законов развития природы, общества и человечества, которые входили в образовательные программы прошлых лет, не представляется реальным из-за невозможности увеличения учебной нагрузки. Поэтому путь разрешения возникшего противоречия между всевозрастающими потоками информации, обязательной для познания молодежью, и нехваткой времени на ее усвоение, ученые увидели в процессе слияния смежных областей знания в единую предметную целостность, а способы их преподнесения - в единую процессуальную общность, что в общих чертах и определило суть педагогической интеграции. 